\title{
Increasing customer loyalty through customer engagement in the retail banking industry
}

\section{La mejora de la lealtad a través del compromiso del cliente en el sector bancario}

\author{
Diego Monferrer, Miguel Angel Moliner and Marta Estrada \\ Department of Business and Marketing, Jaume I University, Castellón, Spain
}

\begin{abstract}
Purpose - This study aims to determine the main antecedents of customer engagement (market orientation, satisfaction, emotions and self-brand connection) and the relationship between customer engagement and customer loyalty in the retail-banking context.

Design/methodology/approach - A theoretical model of effects is tested using dyadic methodology, based on 225 dyads (bank branch manager-average of five branch customers). The authors use structural equation modelling (EQS 6.1) to test the relationships.

Findings - The results reveal a strong relationship between customer engagement and customer loyalty. Satisfaction is the main antecedent of customer engagement. Self-brand connection and emotions during the service also have a significant influence. Finally, branch market orientation has a positive influence on satisfaction and emotions.

Research limitations/implications - The first concerns the transversal data used. Geographical context is the second limitation. Third, the study sample only included customers with experience of the financial services of a specific bank (online customers are not included). Finally, the dyads are based on the opinion of the branch manager, on one hand, and an average of five customers per branch, on the other.

Practical implications - The combination of the branding strategy at the corporate level and the relationship marketing strategy at branch office level creates a situation in which customer engagement and customer loyalty can thrive. The communication campaigns designed to promote the brand image and associate brand values with the personality of the banks' current and potential customers help to create an emotional bond that represents a switching cost for the customer. The moments of truth in branch offices are crucial aspects in the retail bank strategy.
\end{abstract}

(C) Diego Monferrer, Miguel Angel Moliner and Marta Estrada. Published in Spanish Journal of Marketing - ESIC. Published by Emerald Publishing Limited. This article is published under the Creative Commons Attribution (CC BY 4.0) licence. Anyone may reproduce, distribute, translate and create derivative works of this article (for both commercial \& non-commercial purposes), subject to full attribution to the original publication and authors. The full terms of this licence may be seen at http://creativecommons.org/licences/by/4.0/legalcode

The authors gratefully acknowledge the financial support provided by the Spanish Ministry of Economy and Competitiveness via the research project "La confianza del consumidor respecto a la calidad de la relación y la orientación al mercado de las entidades financieras: los efectos de la crisis" (ECO2013-47134-P).

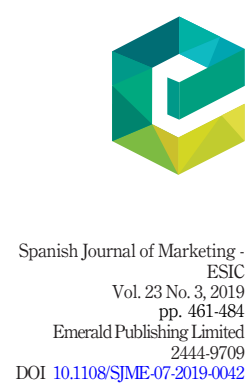


Originality/value - First, from the conceptual perspective, it establishes a direct relationship between customer engagement and customer loyalty. Second, it empirically tested Pansari and Kumar's (2017) customer engagement framework, which establishes customer satisfaction and customer emotions as the antecedents of customer engagement. Third, the study took an innovative step in establishing two levels of customer emotions in the retail bank context: emotions generated by corporate branding and emotions that arise during the experience of purchase and consuming. Fourth, the study shows that the market orientation adopted not at the macro corporate level but at the individual branch level is crucial to the generation of positive relational outcomes in the service the customer receives. The fifth contribution is related to the fact that the research streams associated with market orientation and relationship quality have traditionally been studied in isolation.

Keywords Customer loyalty, Emotions, Market orientation, Satisfaction, Customer engagement, Retail bank industry

Paper type Research paper

\section{Resumen}

Propósito - Este estudio identifica los principales antecedentes del compromiso del cliente (orientación al mercado, satisfacción, emociones y conexión con la propia marca) así como la relación entre compromiso y lealtad en la banca minorista.

Metodología - Se contrasta un modelo de efectos utilizando la metodología de diadas, basada en 225 asociaciones (director de la sucursal bancaria-promedio de cinco clientes por sucursal). Las relaciones se contrastan usando SEM(EQS 6.1).

Limitaciones - El trabajo presenta diversas limitaciones como son el empleo de datos transversales, su aplicación en el mercado español, la inclusión de exclusiva de clientes con experiencia con un banco específico y no operan exclusivamente online. Por último, las díadas se basan en la opinión del director de la sucursal, por un lado, y de una media de cinco clientes por sucursal, por otro.

Implicaciones - La combinación de la estrategia de marca a nivel corporativo y la estrategia de marketing relacional a nivel de sucursal crea una situación en la que el compromiso y la lealtad del cliente pueden desarrollarse. Las campañas de comunicación diseñadas para promover la imagen de marca y asociar los valores de marca con la personalidad de clientes actuales y potenciales ayudan a crear un vínculo emocional que supone un coste de cambio para el cliente. Los momentos de verdad en las sucursales son aspectos cruciales en la estrategia de la banca minorista.

Originalidad - Primero, se establece una relación directa entre el compromiso y la lealtad del cliente. Segundo, se contrasta la satisfacción y las emociones del cliente son antecedentes del compromiso. Tercero, se establecen dos niveles de emociones del cliente en banca minorista: las generadas por el branding corporativo y las que surgen durante la experiencia de compra. Cuarto, el estudio muestra que la orientación de mercado adoptada a nivel de oficina es crucial para generar resultados relacionales positivos con el cliente. Quinto, se combinan las corrientes de investigación asociadas con la orientación al mercado y la calidad de las relaciones.

Palabras clave - Compromiso del cliente, Lealtad del cliente, Satisfacción, Emociones, Orientación al mercado, Banca minorista

Tipo de artículo - Trabajo de investigación

\section{Introduction}

The retail banking industry has undergone major changes in the past years, leading to mergers and the entry of new online financial operators that clearly differ from traditional banking businesses (Csikósová et al., 2016). These changes have led to growing concerns about profitability and productivity in banks, which have introduced marketing strategies designed to attract and retain customers (Gensler et al., 2013). The best global brands in the retail banking industry (HSBC, Citi, Santander) have adopted a strategy that integrates branding at the corporate level and relationship marketing in branch offices, designed to attract customers and win their loyalty by combining a powerful brand image with direct relational interventions in their customer interactions. Most of the large banks are now following this strategy in an 
attempt to increase their competitiveness through branding and relationship marketing. Although the banking sector has attracted a great deal of academic research (Serna, 2005; De Matos et al., 2009; El-Manstrly et al., 2011; Ferreira et al., 2016), few studies have jointly analysed this strategy of customer loyalty based on branding and relationship marketing.

The customer loyalty construct has been explored extensively in the marketing literature (Dick and Basu, 1994; Oliver, 1999; Kumar et al., 2013; Kamran et al., 2017). Although its antecedents, dimensionality and consequences have all been analysed (Oliver, 1999; Kumar et al., 2013); in recent years other pertinent areas of study have emerged in the literature and are attracting growing interest. One such area of recent interest is the role customer engagement plays in forming customer loyalty (Kumar et al., 2013; Thakur, 2016; Kosiba et al., 2018; Moliner et al., 2018; Parihar et al., 2019).

According to Pansari and Kumar (2017), towards the close of the past century and the beginning of the new millennium, companies aimed to foster positive relationships with their customers and secure their loyalty and satisfaction. However, research has shown that customer satisfaction alone is not sufficient to secure their loyalty. As a result, in recent years academic interest has turned to the question of customer engagement, particularly the importance of emotional bonds. This new context led Pansari and Kumar (2017) to suggest that customer management has entered a new stage of engagement, while trust and commitment predominated in the preceding relationship-centred stage, in these new times the key to customer management lies in satisfaction and emotion.

Some data show the increasingly important role of customer engagement at the business level. More than 80 per cent of marketers aim to win over engaged customers so as to strengthen advocacy and build trust (Pansari and Kumar, 2017). In the retail banking industry, these authors also found that fully engaged customers bring 37 per cent more annual revenue to their primary bank than actively disengaged customers (Pansari and Kumar, 2017). Customer engagement should therefore be incorporated into explanatory models of customer loyalty. Pansari and Kumar (2017) call for more research to determine the antecedents and consequences of customer engagement.

The present study aims to determine the main antecedents of customer engagement (market orientation, satisfaction, emotions and self-brand connection) and the relationship between customer engagement and customer loyalty in the retail-banking context. To this end, we propose a causal model that considers two levels of antecedent influence on engagement: first, the influence on the customer at the corporate level measured through the construct of self-brand connection; and second, and more closely focused on the scope of this study, the influence of variables generated by the customer during the service experience in the branch, namely, satisfaction and emotions during the service.

To this end, in Sections 2, 3 and 4, we propose a causal model that considers two levels of antecedent influence on engagement: first, the influence on the customer at the corporate level measured through the construct of self-brand connection; and second, and more closely focused on the scope of this study, the influence of variables generated by the customer during the service experience in the branch, namely, satisfaction and emotions during the service.

In this context, the present study aims to contribute to the literature by examining, from the branch perspective, the extent to which the degree of market orientation adopted and implemented in the branch at the individual internal level can facilitate customer satisfaction and emotions. In Section 5, we explain the methodology of the research. A dual focus of analysis leads us to test this model by constructing dyads from a double sample of 1,125 customers from 225 bank branches and the managers of these branches. In Section 6,
Retail banking
industry

463 
SJME 23,3

results are presented, and Section 7 closes with discussion, managerial implications, limitations and future research.

\section{Customer engagement}

In the past 10 years, customer engagement has attracted increased research attention (Bowden, 2009; Sprott et al., 2009; van Doorn et al., 2010; Brodie et al., 2011; Hollebeek, 2011; Kumar et al., 2013; Hollebeek and Chen, 2014; Pansari and Kumar, 2017; Roy et al., 2018; Moliner et al., 2018). In light of the growing importance of the role of social media conversations, referrals and service co-creation, some marketing researchers are now studying customer engagement as a way to explain voluntary customer behaviours that go beyond the transaction: customer non-transactional behaviours (van Doorn et al., 2010).

Pansari and Kumar's (2017) valuable reflections on the customer engagement framework have clarified its scope, defining it as "the mechanics of a customer's value addition to the firm, either through direct or/and indirect contribution" (p. 295). This definition emphasises the transactional (direct contributions such as purchases) and non-transactional (indirect contributions such as word-of-mouth, henceforth WOM) customer behaviours that add value to the company. However, to identify the essence of customer engagement we must turn to Bowden (2009), Sprott et al. (2009), Hollebeek (2011), Brodie et al. (2011), Hollebeek and Chen (2014) and Pansari and Kumar (2017) who understand customer engagement as a combination of rational and emotional bonds generated through experiences with the brand/firm. In other words, according to the psychology literature, engaged partners' experience of the relationship is more satisfying and they have a stronger emotional connection with the firm (Kitayama et al., 2000). This is the approach followed in this research.

Pansari and Kumar (2017) describe the process by which customer engagement is developed as follows. Marketing activities for a brand create customer awareness about promoted products and services. This awareness helps the customer to understand what the firm is offering and triggers the desire to purchase. Customers' experiences of the purchasing act can be positive or negative, generating a certain level of satisfaction and emotions about the brand/firm (Verleye, 2015; Cambra et al., 2016). If the customer has a positive level of satisfaction, they will be likely to repurchase, and if emotions are positive, they should generate non-transactional behaviours (Verhoef et al., 2010; Klaus et al., 2013; Chahal and Dutta, 2015).

\section{The antecedents of customer engagement}

Pansari and Kumar's (2017) framework proposes two antecedents for customer engagement: the level of satisfaction the customer obtains from the relationship and the level of emotional connectedness the customer has with this relationship. The retail banking industry combines a branding strategy at the corporate level with a relationship marketing strategy at the branch office level. This implies that expectations and emotions are generated at two different levels: corporate and branch (Ou et al., 2017). In the present study, together with satisfaction, we therefore, include two emotional variables that aim to capture the emotions generated in these two spheres: selfbrand connection at the corporate level and emotions during service at the branch office level.

Our proposal is also in line with the customer engagement framework (Pansari and Kumar, 2017), since in the customer management process the brand or firm's marketing activities are understood to generate awareness among customers that motivates their desire to purchase (branding). In the moment of truth, that is, the interaction between the firm and the customer, satisfaction and emotions are generated during the service (branch office). In other words, from the customer experience perspective, emotions are generated in three stages: pre-purchase (branding), purchase (branch office) and post-purchase (Ou et al., 2017). 


\subsection{Customer self-brand connection as an antecedent of customer engagement at the}

corporate level

Escalas and Bettman (2005) define customer self-brand connections as "the extent to which industry

individuals have incorporated brands into their self-concept" (Escalas, 2004; Escalas and Bettman, 2005). Consumer self-congruity is the psychological theory that underlies selfbrand connection as it concerns the coincidence between the consumer's self-concept and the attributes and values of the service, product and/or supplier (Sirgy, 1985). Self-congruity theory identifies four kinds of self (actual self, ideal self, social self and ideal social self) and posits that the higher the self-congruity between these four types and the attributes of a service or product, the greater the likelihood of the consumer acquiring or purchasing the service or product, and of performing non-transactional behaviours (Sirgy et al., 2008).

Self-brand connection analyses the degree to which the consumer's identity is connected to the brand and plays a major role the consumer's actual or ideal self-expression (Chaplin and John, 2005; Aguirre et al., 2012). Self-brand connection is generated by the brand or firm's pre-purchase communication activities that create customer awareness and persuade them to purchase from the firm. Self-brand connection implies an association with the brand that may meet a person's psychosocial needs, give them a stronger sense of identity and enhance their connections with other people (Kemp et al., 2014).

Self-brand connection is therefore an emotional variable that gathers the extent to which the customer's personality is connected to the brand's values. It captures the pre-purchase communication activities the brand enacts to attract and persuade consumers and, according to Pansari and Kumar (2017), positively influences customer engagement by creating an emotional bond between the customer and the firm:

\section{H1. Customer self-brand connection positively influences customer engagement.}

\subsection{The antecedents of customer engagement at the branch level}

As described above, in the process of customer interaction with the branch, the factors of satisfaction and emotions during the service are identified as direct antecedents of the customer's engagement (Ou et al., 2017; Pansari and Kumar, 2017).

Our study aims to take a further step by examining an additional question: to what extent does the degree to which branches adopt an intensive marketing focus affect the generation of these two antecedent variables? This aspect is generally considered in the literature to be covered by the construct of market orientation (Kohli and Jaworski, 1990; Narver and Slater, 1990).

3.2.1 Customer satisfaction and customer engagement. Customer satisfaction is "a judgment that a product/service feature, or the product or service itself, provided (or is providing) a pleasurable level of consumption-related fulfillment including levels of underor overfulfillment" (Oliver, 1999). The process by which customer satisfaction is formed can be explained by the expectancy-disconfirmation paradigm (Oliver, 1999). This expectationdisconfirmation model is premised on the idea that customers' expectations about a product or service develop prior to purchase; they then contrast these expectations with the reality of the purchase experience itself, and following the purchase.

There have been no in-depth studies into the customer satisfaction-customer engagement relationship as yet, although it seems fairly evident that a satisfied customer would have a higher level of engagement with the brand or the firm (Bowden, 2009; van Doorn et al., 2010; Pansari and Kumar, 2017). Füller (2010) confirms that satisfaction leads to customer engagement, although these combinations can differ from one customer to another. Van Doorn 
SJME 23,3

et al. (2010) and Pansari and Kumar (2017) understand customer satisfaction to be an antecedent of customer engagement behaviour (Anderson and Mittal, 2000; Palmatier et al., 2006). Brodie et al. (2011) suggest that some highly engaged consumers have experienced previously higher levels of satisfaction. From the literature review, we therefore propose that as levels of customer satisfaction increase, customer engagement will become more positive, even though the empirical evidence for this conjecture is scant:

H2. Customer satisfaction positively influences customer engagement.

3.2.2 Emotions during the service and customer engagement. The emotions generated in customer experiences during the service delivery are considered to be an antecedent of customer engagement (Bagozzi et al., 1999; Pansari and Kumar, 2017). The moments of truth that occur in service encounters are not only a crucial factor in generating customer satisfaction but also responsible for causing positive or negative emotions that customers store in their memory and that will influence their transactional and non-transactional behaviours (Pansari and Kumar, 2017). According to Bagozzi et al. (1999), "coping with positive emotions often involves sharing one's good fortune, savoring the experience, working to continue or increase the rewards, and increasing physical activity". From emotions come tendencies to action, "a readiness to engage in or disengage from interaction with some goal object" (Frijda et al., 1989: 213). When there is a high level of emotional engagement with the service or product, the stimulus provokes strong affective reactions in consumers, which may have an influence on their attitudes (Martin et al., 2008). Garg et al. (2005) consider that consumers' affective states, such as disgust, regret and anger, can affect customer engagement behaviours. According to van Doorn et al. (2010), an extreme positive or negative experience of a brand or a firm can influence customer engagement behaviours, whereas "a series of delightful experiences may motivate a customer to set up a brand community, or engage in positive WOM". Emotions during the service therefore play a central role in customer engagement, such that positive emotions generate favourable engagement. These arguments lead us to our final hypothesis:

H3. Customer emotions during the service positively influence customer engagement.

\subsubsection{Branch market orientation as a facilitator of customer satisfaction and customer} emotions during the service. In the past 30 years, market orientation has become established as a fundamental variable in the marketing literature (Han et al., 1998; Flavián and Lozano, 2006; Theodosiou et al., 2012; Monferrer et al., 2019). Most studies define market orientation according to one of two seminal conceptualisations, from either a cultural or a behavioural approach. The cultural approach is concerned with the organisational norms and values that promote behaviours consistent with close attention to the customer, competitors and the environment (Narver and Slater, 1990). The behavioural approach emphasises specific attitudes related to the generation and dissemination of and responsiveness to market intelligence (Kohli and Jaworski, 1990). However, there is now a broad consensus that the two perspectives are perfectly complementary and a holistic approach can be taken by considering them together (Kolar, 2006; Zhou et al., 2008; Monferrer et al., 2019).

From this combined perspective, market orientation is a strategic orientation based on managing market knowledge that is built on the organisation's firm commitment to develop a set of processes, beliefs and values that reflect the fundamental principle of marketing (Monferrer et al., 2019). This principle holds that all the decisions taken in the company start with the customer and are grounded on a deep shared understanding of his or her needs and behaviours to achieve greater performance than its competitors through customer 
satisfaction and by providing a higher value service or product (Han et al., 1998; Kolar, 2006; Theodosiou et al., 2012; Fang et al., 2014).

Based on its own definition, developing a market orientation will help branches to generate and disseminate their own branch-specific market information and will motivate their contact personnel to offer services in the optimal way (Lings and Greenley, 2009). The implication of this shared internal orientation grounded in a marketing rationale is that branch employees will take a proactive approach to gathering information on what their customers need, both now and in the future, and on what factors might condition their behaviour (Fang et al., 2014). Branches with a market orientation therefore have an advantage in achieving customer satisfaction and a service experience associated with positive emotions since they can align the internal development of their mechanisms, routines and capabilities with the external efforts they make on their customers' behalf according to the conditions existing in the market, and maintain the symmetry between them (Zhang and Duan, 2010; Monferrer et al., 2019). Therefore, we propose that:

H4. Branch market orientation positively influences customer satisfaction.

H5. Branch market orientation positively influences customer emotions during the service.

\section{The consequences of customer engagement}

Customers' actions are the result of their degree of engagement with the brand or firm (Pansari and Kumar, 2017). These actions take the form of purchases, incentivised referrals by the customer, conversations about the brand and the customer's feedback on social media and ideas about how the firm could improve performance (Kumar et al., 2013).

According to the customer engagement framework (Pansari and Kumar, 2017), one consequence of this engagement is customer loyalty. Consumer or customer loyalty may be defined in terms of repeat purchase behaviour or as a consumer attitude to the brand or firm (Kumar et al., 2013; Kamran et al., 2017). Although the most practical approach is to consider loyalty in terms of repeat purchase, methodologically this is problematic because it implies attempting to explain past behaviour from psychological variables measured a posteriori. In fact, Dick and Basu (1994) contend that repeat purchase might not reflect true loyalty. From the psychological and methodological perspectives, therefore, it is more appropriate to examine attitudinal loyalty, since the data are obtained at the same point in time; indeed attitude is the most reliable predictor of future behaviour. Attitudinal loyalty reflects the psychological predisposition the consumer has towards a brand or firm (Roy et al., 2018).

As noted above, Pansari and Kumar (2017) understand customer attitudinal loyalty as a consequence of customer engagement. Some scholars have suggested customer engagement directly influences customer attitudinal loyalty (Bowden, 2009; van Doorn et al., 2010). Jaakkola and Alexander (2014) regard loyalty as an outcome arising from customer engagement. Harrigan et al. (2018) consider that customers' engagement with the brand predicts intent to use the brand. The literature therefore understands customer engagement as a psychological predisposition, an emotional connection with a brand or a firm that generates consumer loyalty. Therefore, and following Kumar et al. (2013) and Pansari and Kumar (2017), we propose that customer engagement is directly related to customer attitudinal loyalty:

H6. Customer engagement positively influences customer loyalty.

In summary, as shown in Figure 1, we propose a model of effects associated with the service experienced by bank customers in their branches.
Retail banking industry

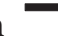


Figure 1.

Model of effects

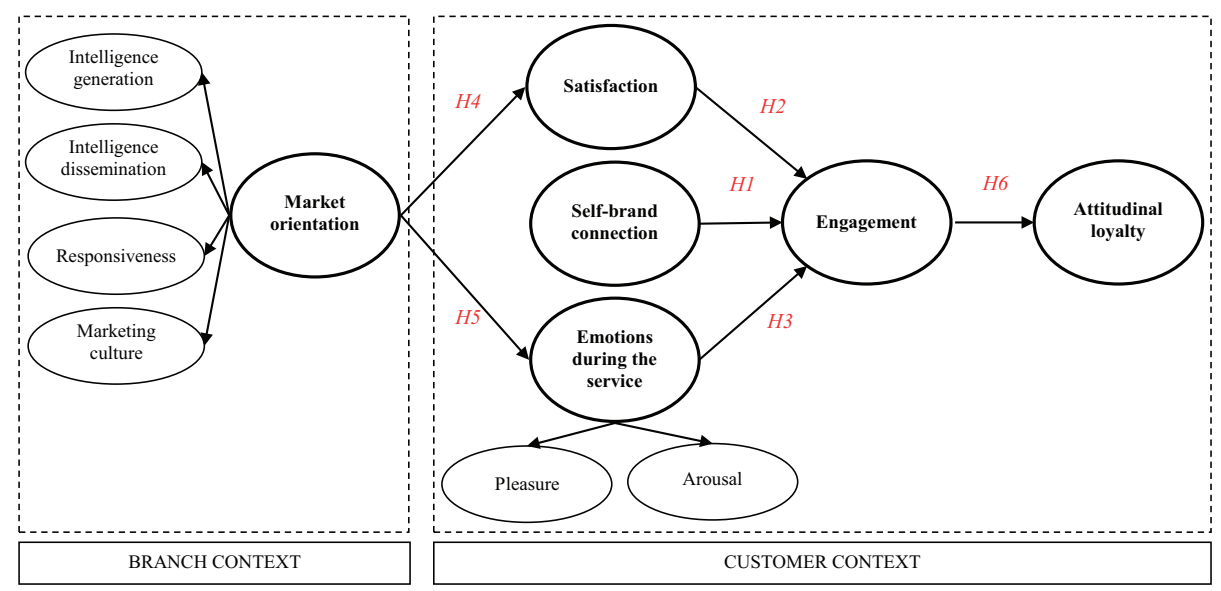

\section{Methodology}

\subsection{Data collection and sample}

The universe for the study comprised 530 bank branches from a major Spanish bank in the provinces of Valencia, Castellón, Alicante and Murcia.

A two-sample research design using two different questionnaires was appropriate for this study because of the conceptual integration of the branch managers' and the customers' perceptions. The first questionnaire measured the managers' assessment of market orientation in their branch, whereas the second one captured customers' overall perceptions of the self-brand connection and their perceived satisfaction, emotions during the service, engagement and loyalty to their branch.

Prior to administering the questionnaires, the bank's senior marketing managers participated in group activities to verify that the questionnaires aligned with the reality of the firm. These activities included conversations about the role physical branches play in guaranteeing customers' relationship quality and attempted to define the key factors that could be enhanced at the branch level to achieve this goal.

We followed the recommendations of Ye et al. (2007) in the questionnaire design to counter "self-generated validity" by carefully ordering the questions in the survey, using terminology and language respondents would find easy to understand, and ensuring that the constructs analysed did not appear in the questionnaire in the same order as in the hypotheses (antecedents $\rightarrow$ mediating variable $\rightarrow$ consequences). At the end of 2015, pretests were conducted with the questionnaire items in personal interviews with 10 bank branch managers and 25 customers.

Managers and customers were then interviewed during the fieldwork stage from January to March in 2016. The interviews with the managers took place in their branch offices, and in each case five customers were randomly chosen for interview while they were waiting to be served in the branch. The customers were screened to ensure that only regular customers at the branch were included in the sample.

Professional interviewers conducted the interviews for both the studies to ensure that a standard structure was followed, and that respondents fully understood all the questions. In addition, we followed the recommendation by Hox (1994) to use the intra-class correlation coefficient (ICC) to prevent significant interviewer effect on the results. The results of the ICC were close to 0.031 , which meets the thresholds for face-to-face surveys recommended in the literature (Davis et al., 2010). 
The managers' sample yielded a response rate of 42.45 per cent (225 of the 530 branches). On average, these bank branches had between five and six employees (between two and five in 59.2 per cent of the branches; between 6 and 10 in 34.5 per cent, and just 6.3 per cent with over 10 employees).

The second sample was made up of 1,125 customers, 540 of whom were women (48 per cent) and 585, men (52 per cent). Their average age was 47 (15 per cent between 18 and 29; 20 per cent between 30 and 39; 21 per cent between 40 and 49; 19 per cent between 50 and 59; and 14 per cent between 60 and 69). An analysis of the primary data revealed the main characteristics of the customer sample (Table I), which were analogous to the total population of customers in the branches included in the study.

The branch manager-customer relationship was the unit of analysis in the study; therefore, the research hypotheses were tested on 225 dyads associating each branch manager's results with the average results of the five customers interviewed the same branch. Average scores were rounded to eliminate decimals, thus maintaining the ordinal nature of the customer variables in the calculations. This aggregation follows recommendations in the literature (Yoon and Suh, 2003) that data should be gathered at the level of analysis at which it will be aggregated. However, Schneider and Bowen (1985) point out that the customers' ratings must be reasonably stable within each service encounter. To test consistency or agreement across customers' responses on their satisfaction, self-brand connection, emotions during the service (pleasure and arousal), engagement and loyalty, within-group inter-rater agreement was estimated for these constructs (James, 1982).

The average within-group inter-rater reliability values, $\mathrm{rwg}(\mathrm{j})$, for those constructs were $0.80,0.70,0.84,0.79,0.70$ and 0.80 , respectively; all these values are equal to or above the commonly accepted threshold of 0.7, suggesting sufficient within-group agreement to aggregate the data at branch level. We also assessed inter-rater reliability (Batko, 1976) among branches using ICC statistics, ICC (1) and ICC (2). Again, the ICC (1) values exceeded the threshold value of 0.12 (James, 1982), reaching 0.30, 0.28, 0.34, 0.30, 0.27 and 0.32 for customer perceptions of satisfaction, self-brand connection, emotions during the service (pleasure and arousal), engagement and loyalty, respectively; the variability ratio can therefore be considered sufficient. Inter-rater reliability among branches was also sufficient with ICC (2) values of 0.70 , $0.69,0.74,0.70,0.68$ and 0.72 , respectively, higher than the threshold of 0.60 (Glick, 1985). The above results therefore justify aggregating the data by customers at the branch level.

\subsection{Measurement instruments}

The scales used to measure the constructs correspond exactly to their theoretical definitions. In all cases, we adapted scales that other authors had already tested in previous studies,

\begin{tabular}{|c|c|c|c|c|c|c|c|}
\hline \multirow{2}{*}{$\begin{array}{l}\text { Age } \\
\text { Years }\end{array}$} & \multirow[b]{2}{*}{$(\%)$} & \multicolumn{2}{|c|}{ Occupation } & \multicolumn{2}{|l|}{ Education level } & \multicolumn{2}{|c|}{ Income level } \\
\hline & & Rank & $(\%)$ & Level & $(\%)$ & Level & $(\%)$ \\
\hline $18-29$ & 15 & Student & 10 & No studies & 4 & $€ 0-€ 1,000$ & 18 \\
\hline 30-39 & 20 & Employed & 50 & Primary education & 15 & $€ 1,001-€ 1,500$ & 28 \\
\hline $40-49$ & 21 & Homemaker & 10 & Secondary education & 19 & $€ 1,501-€ 2,000$ & 24 \\
\hline $50-59$ & 19 & Retired & 20 & High school diploma & 30 & $€ 2,001-€ 2,500$ & 13 \\
\hline $60-69$ & 14 & Unemployed & 10 & Higher education & 32 & $>€ 2,500$ & 17 \\
\hline$>70$ & 11 & & & Gender & & & \\
\hline Averag & & & & $\begin{array}{l}\text { Rank } \\
\text { Men } \\
\text { Women }\end{array}$ & $\begin{array}{l}(\%) \\
52 \\
48\end{array}$ & & \\
\hline
\end{tabular}

Retail banking
industry

469

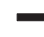


SJME

23,3

tailored to our study context, namely, the bank branch. All the questionnaire items were closed attitudinal questions answered on a five-point Likert scale, where 1 denoted complete disagreement (lowest agreement), and 5 complete agreement (highest agreement). Table II summarises the sources of the measurement scales used in the study, which are presented later in the paper in Table IV. The covariance matrix is displayed in Table III.

We applied Kolar's (2006) multidimensional scale to measure the market orientation of the branches. Although this scale was originally designed for use in the banking context in transitional economies, its definition is global and generalised, making it perfectly possible to use in any banking context such as the Spanish financial industry (Monferrer et al., 2019). Concretely, from a holistic approach the scale consists of four dimensions corresponding to the behavioural and cultural perspectives associated with the construct (Kohli and Jaworski, 1990; Narver and Slater, 1990): intelligence generation (four items), intelligence dissemination (four items), responsiveness (four items) and marketing culture (four items).

We adapted Mazaheri et al.'s (2011) scale to the study context (the bank branch) to measure the emotions customers experienced during the service. This multidimensional scale conceives these emotions in terms of two dimensions related to individuals' emotional categories: pleasure (six items) and arousal (three items).

Blasco's (2014) four-item scale was used to measure the level of customers' engagement with their branch, again tailored to the bank branch context. This scale matches Pansari and Kumar's (2017) approach of customer engagement and draws on previous measurement scales by Medlin and Green (2009) and Sprott et al. (2009).

We measured customers' self-brand connection using a four-item scale proposed by Kemp et al. (2014), adapted from earlier scales devised by Escalas and Bettman (2005).

Finally, we measured satisfaction with an adaptation of Bloemer and Odekerken's (2002) scale, and attitudinal loyalty with Camarero et al.'s (2005) scale. Both are five-item scales.

\subsection{Validity and scale reliability}

We performed confirmatory factor analysis (CFA) using structural equation modelling (SEM) to refine the scales with the EQS multivariate software package (version 6.1). The maximum likelihood approach was adopted to estimate the parameters.

We first tested the variance inflation factor (VIF) among the latent variables in the overall model to detect signs of multicollinearity. The values were lower than 10 (Hair et al., 2010), indicating that multicollinearity was not a problem in our study. We then performed a one-factor test among the latent variables in the proposed model to rule out common method bias resulting from the way the data were collected (Podsakoff et al., 2003). The results of the CFA with the proposed factor structure yielded a significantly better overall fit, implying that a single factor does not reflect the data well, and indicating the possible absence of any common method bias in collecting the data (Farrell and Oczkowski, 2009).

\begin{tabular}{llcll}
\hline Variables & References & Dimensions & Items & Scale \\
\hline Market orientation & Kolar (2006) & 4 & $16(4+4+4+4)$ & Likert 5 points \\
Satisfaction & Bloemer and Odekerken (2002) & 1 & 5 & Likert 5 points \\
Self-brand connection & Kemp et al. (2014) & 1 & 4 & Likert 5 points \\
Emotions during the service & Mazaheri et al. (2011) & 2 & $9(6+3)$ & Likert 5 points \\
Engagement & Blasco (2014) & 1 & 4 & Likert 5 points \\
Attitudinal loyalty & Camarero et al. (2005) & 1 & 5 & Likert 5 points \\
\hline
\end{tabular}

Table II.

Scales used

\section{Engagement
Attitudinal loyalty}

Camarero et al. (2005) 


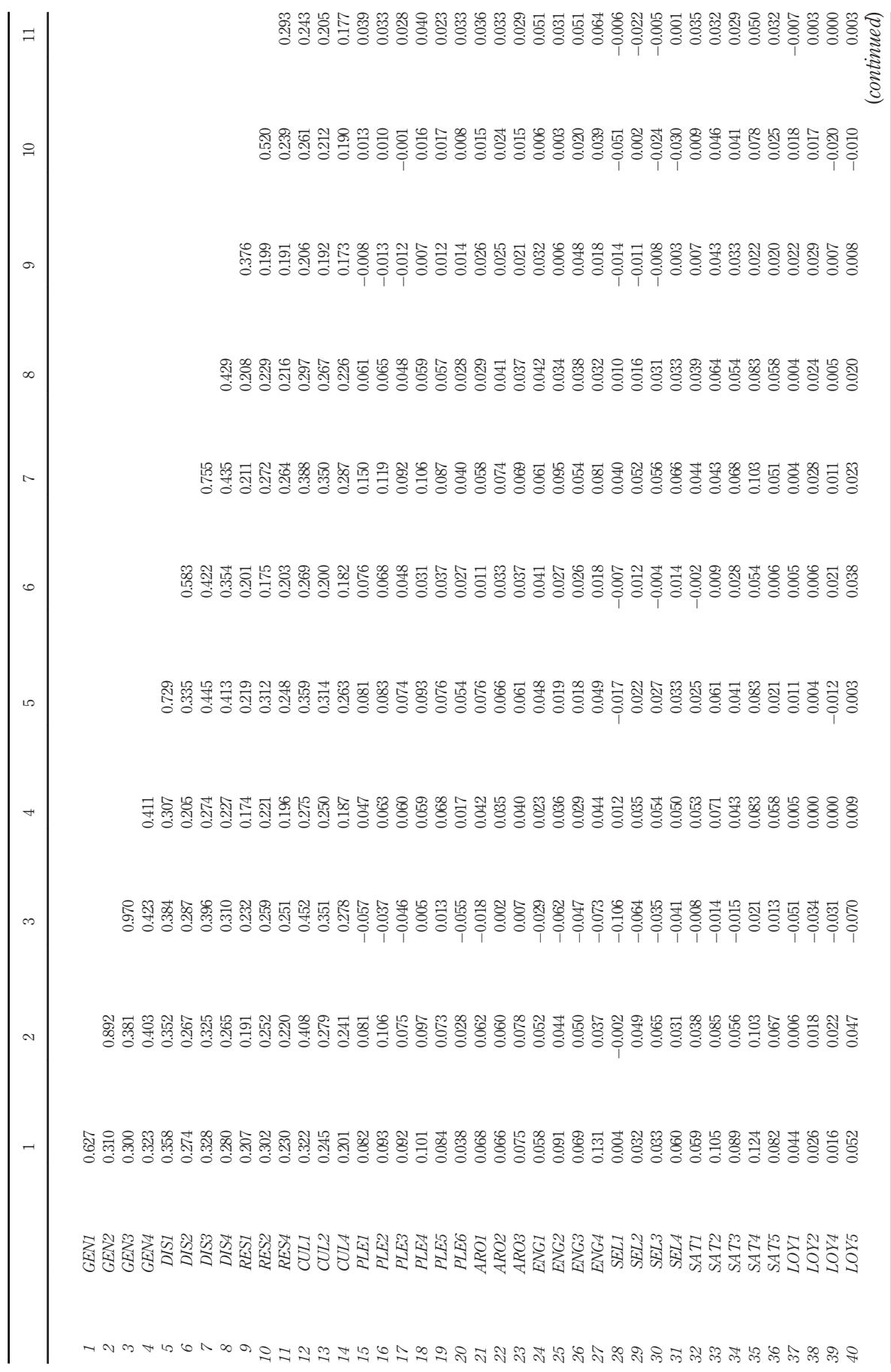

Retail banking industry

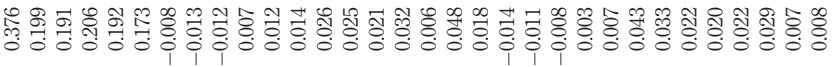

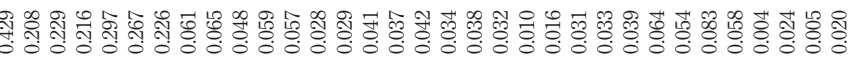

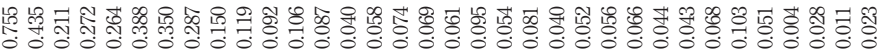

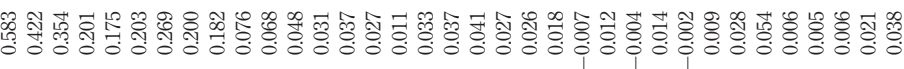

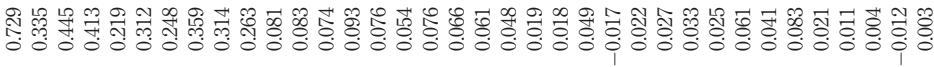

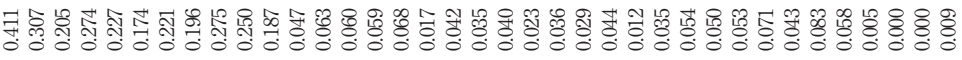

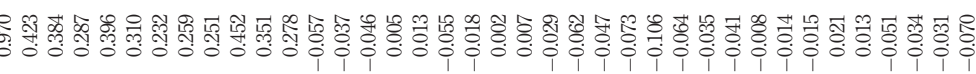

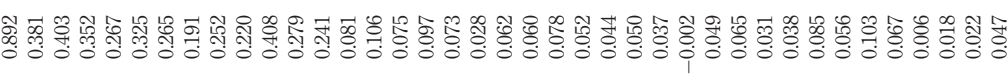

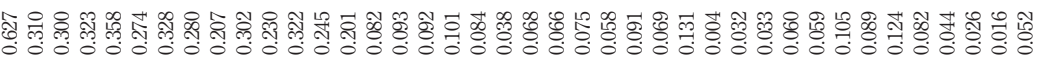

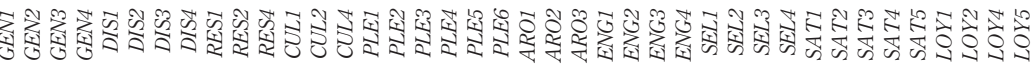

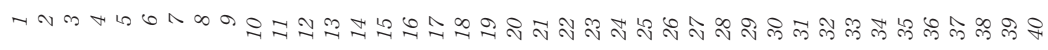

Table III. Covariance matrix for the variables $(N=225)$ 
SJME
23,3

472

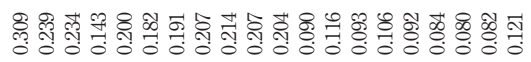

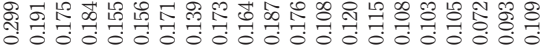

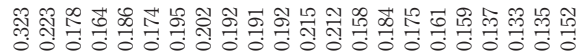

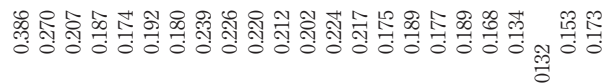

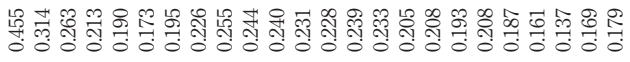

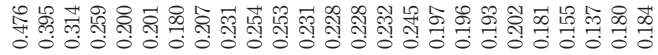

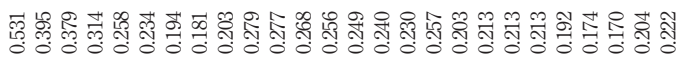

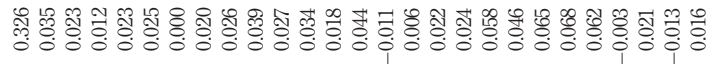

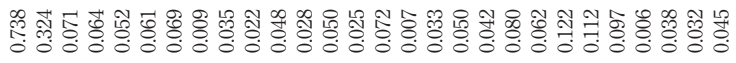

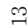

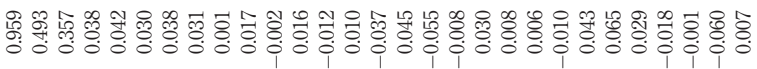

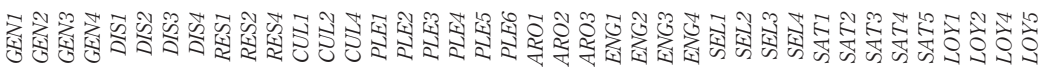

Table III.

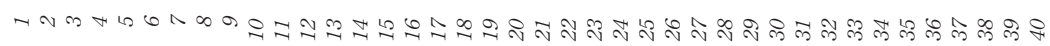




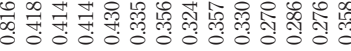

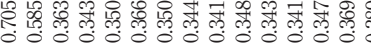

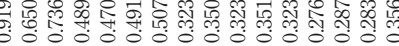

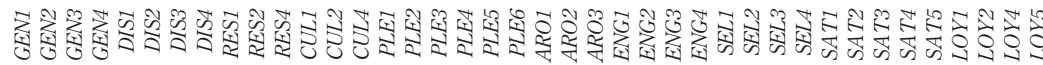




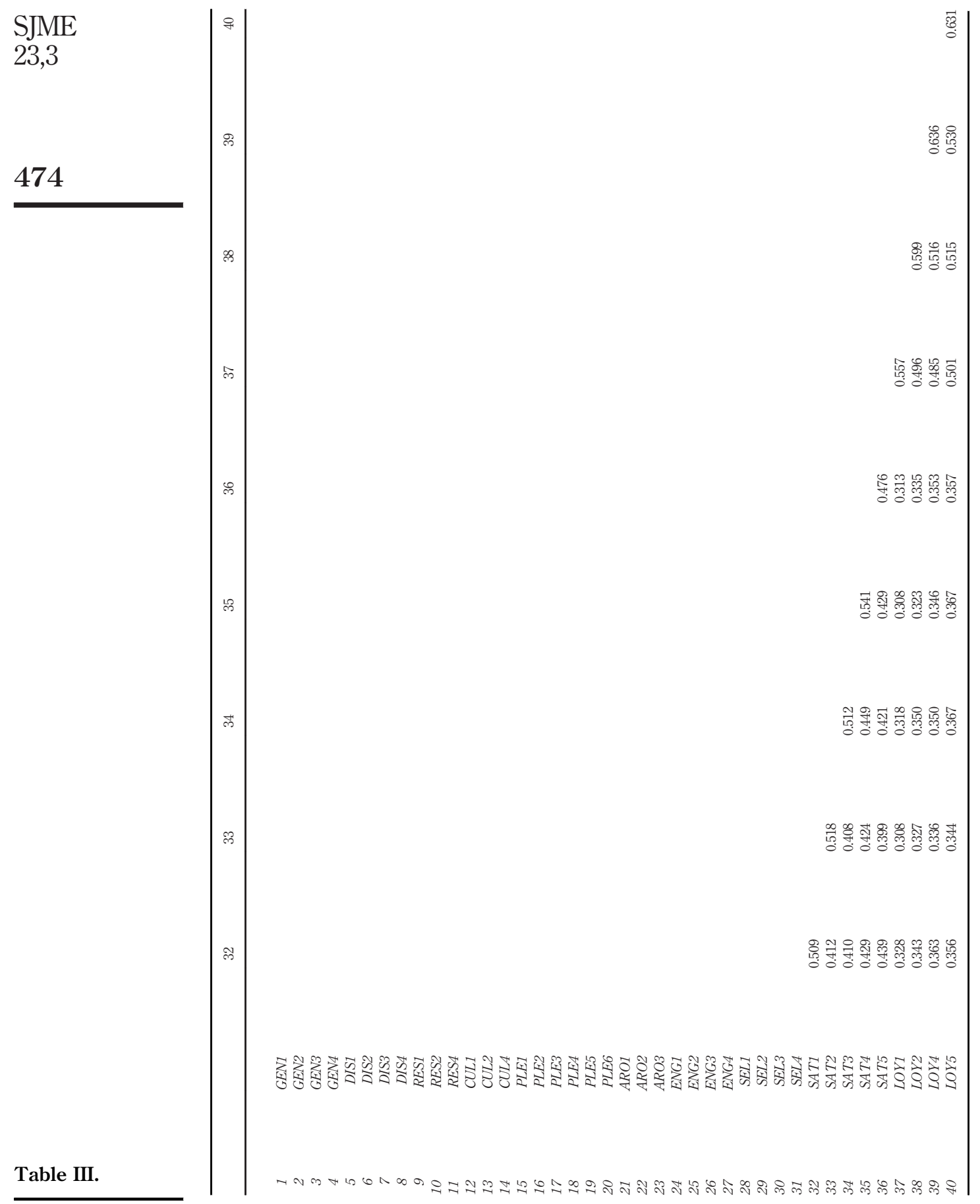


The next stage followed a model development strategy (Hair et al., 2010). Taking the latent variable structures assumed for the model constructs as a basis, we proceeded to suppress the least appropriate indicators to improve the initial models. In line with recommendations industry from Jöreskog and Söbom (1993), we first examined the estimation parameters. We eliminated the indicators that did not satisfy the strong convergence condition, that is, those having individual standardised coefficients $(\lambda)$ lower than 0.6 and an average standardised factor loading of less than 0.7 (Steenkamp and Van Trijp, 1991; Hair et al., 2010). We then analysed the significance of the factor regression coefficients between indicators and their corresponding latent variables to verify compliance with the weak convergence condition (Steenkamp and Van Trijp, 1991). To this end, we revised the Student $t$-values by imposing the maximum requirement $(t>2.58 ; p=0.01)$. Following this process three indicators were removed: RES3, CUL3 and LOY3.

Finally, we monitored the evolution of the main model fit measurements as each indicator was eliminated. Specifically, using $\chi^{2}$ statistics we assessed the fit of the conceptual model to the empirical data, the normed fit index (NFI), non-normed fit index (NNFI), the incremental fit index (IFI), the comparative fit index (CFI) and the root mean square of approximation (RMSEA).

We then ran several tests to check whether the refinement process followed in the previous tests had a negative effect on the reliability of the scale. We tested the internal consistency with Cronbach's alpha $(\alpha>0.7)$, and performed construct composite reliability $(\mathrm{CR}>0.7)$ and analysis of variance extracted (AVE $>0.5)$ tests (Churchill, 1979; Fornell and Larcker, 1981). Sufficient guarantee of convergent validity was demonstrated as the correlations were relatively high and significant. Table IV presents a summary of the results following the factor and reliability tests.

We then analysed the convergent and discriminant validity. Convergent validity was demonstrated by going back to the initial CFA performed and comparing the estimated value and significance of the correlations between the dimensions in the two scales. Table $\mathrm{V}$ presents the discriminant validity of the constructs considered, assessed by AVE (Fornell and Larcker, 1981). When the square root of the AVE between each pair of factors is higher than the estimated correlation between those factors, as in our case, discriminant validity is verified.

\section{Results}

Following the same procedure as for validating the scales, we tested the hypotheses using SEM with the EQS multivariate software package (version 6.1). As can be seen in Table VI, all the hypotheses were confirmed; the optimal model fit measurements are also presented in this table.

First of all, the market orientation adopted in each individual branch has a positive and significant effect on the factors associated with the customers' experience of the service, that is, on their satisfaction ( $H 4: \lambda=0.163 ; t=3.220)$ and their emotions during the service (H5: $\lambda=0.203$; $t=3.328$ ). Likewise, these two factors associated with the customers' experience in the branch, together with the overall feeling of connection to the bank are decisive in generating customers' engagement with their bank. The strongest relationship was found for customer satisfaction ( $H 2: \lambda=0.552 ; t=13.643$ ), followed by the relationship for selfbrand connection (H1: $\lambda=0.372 ; t=9.603$ ). Finally there was a weaker, although significant, relationship with customer emotions during the service $(H 3: \lambda=0.218 ; t=$ 5.321). In addition, we found that customer engagement determines a specific related behaviour that gives rise to a strong and positive relationship between customer engagement and customer loyalty $(H 6: \lambda=0.615 ; t=12.893)$. 
Market orientation $(C R=0.91 ; A V E=0.72)$

Intelligence generation $(\alpha=0.795 ; \mathrm{CR}=0.84 ; \mathrm{AVE}=0.58)$

$0.816 \quad 11.888^{*}$

GEN1: We regularly analyse the factors that influence customer satisfaction

$0.686 \quad$ Fixed

GEN2: We regularly analyse the improvement in our employees' satisfaction and compare it with their performance

$0.693 \quad 12.828^{*}$

GEN3: We quickly detect the changes that occur in our commercial environment

$0.702 \quad 11.003^{*}$

GEN4: It is just as important for us to achieve marketing objectives (customer satisfaction and loyalty, service quality) as it is to meet our financial targets

Intelligence dissemination $(\alpha=0.878 ; \mathrm{CR}=0.89 ; \mathrm{AVE}=0.68$ )

$0.926 \quad 16.350^{*}$

DIS1: Our firm's mission is reflected and implemented in our plans and interventions addressing customer satisfaction

DIS2: Customer satisfaction and quality improvement are regularly dealt with in our meetings

$0.85316 .661^{*}$

DIS3: Our targets include specific customer satisfaction and quality improvement objectives

$0.778 \quad$ Fixed

DIS4: We inform about possible future changes in an integrated, logical and objective way, including any possible disadvantages associated with the change and by exploring our employees' opinions

Responsiveness $(\alpha=0.772 ; \mathrm{CR}=0.79 ; \mathrm{AVE}=0.56)$

RES1: We demonstrate our interest in building a closer relationship with customers through a range of actions (such as responding personally to their questions) RES2: We have a structured system for the continued improvement of customer satisfaction and service quality (surveys, customer complaint and relations management, etc.)

RES3: We are ready to face new challenges and learn new skills

RES4: We analyse our main functions to optimise them and minimise their failure rate Marketing culture $(\alpha=0.806 ; \mathrm{CR}=0.83$; AVE $=0.63)$

CUL1: We reward our branch personnel for their contributions to customer satisfaction and for improving service quality

CUL2: We have sufficient authority and information to take decisions flexibly

CUL3: We have the capability to implement innovations without the need for numerous rounds of approval at different levels in the hierarchy

CUL4: The flexible interpretation of the work procedures, norms and policies are not regarded as a problem in our branch

$0.739 \quad 14.823^{*}$

$0.817 \quad 18.771^{*}$

$0.939 \quad 20.005^{*}$

$0.902 \quad 13.566^{*}$

$0.673 \quad$ Fixed

$0.701 \quad 10.695^{*}$ Deleted

$0.861 \quad 16.435^{*}$

$0.830 \quad 13.867^{*}$

0.735 Fixed

$0.750 \quad 16.369 *$

Deleted

Customer satisfaction ( $\alpha=0.959 ; C R=0.96 ; A V E=0.83$ )

SAT1: My expectations have been met

SAT2: I am satisfied with the value for money offered

SAT3: I am satisfied with the service I have received

SAT4: I am satisfied with the company

SAT5: In general I am really satisfied

$0.884 \quad 16.672^{*}$

Customer self-brand connection ( $\alpha=0.960 ; C R=0.96 ; A V E=0.86)$

SEL1: My bank reflects who I am

SEL2: I can identify with my bank

SEL3: I feel a personal connection with my bank

SEL4: My bank matches my personality

Table IV.

Summary of the results after factor, reliability and validity analysis
Customer emotions during the service $(\mathrm{CR}=0.79 ; \mathrm{AVE}=0.65)$

Pleasure $(\alpha=0.929 ; C R=0.93 ; A V E=0.69)$

PLE1: Angry/Glad

PLE2: Sad/Cheerful
0.918

0.870

0.905

0.908

0.944

0.911

0.942

0.927

0.928

0.842

0.842

0.887
$27.518^{*}$

$21.249 *$

22.030*

$27.164^{*}$

27.965*

25.970*

25.804*

26.988*

25.525*

17.460*

Fixed

29.017*

(continued) 


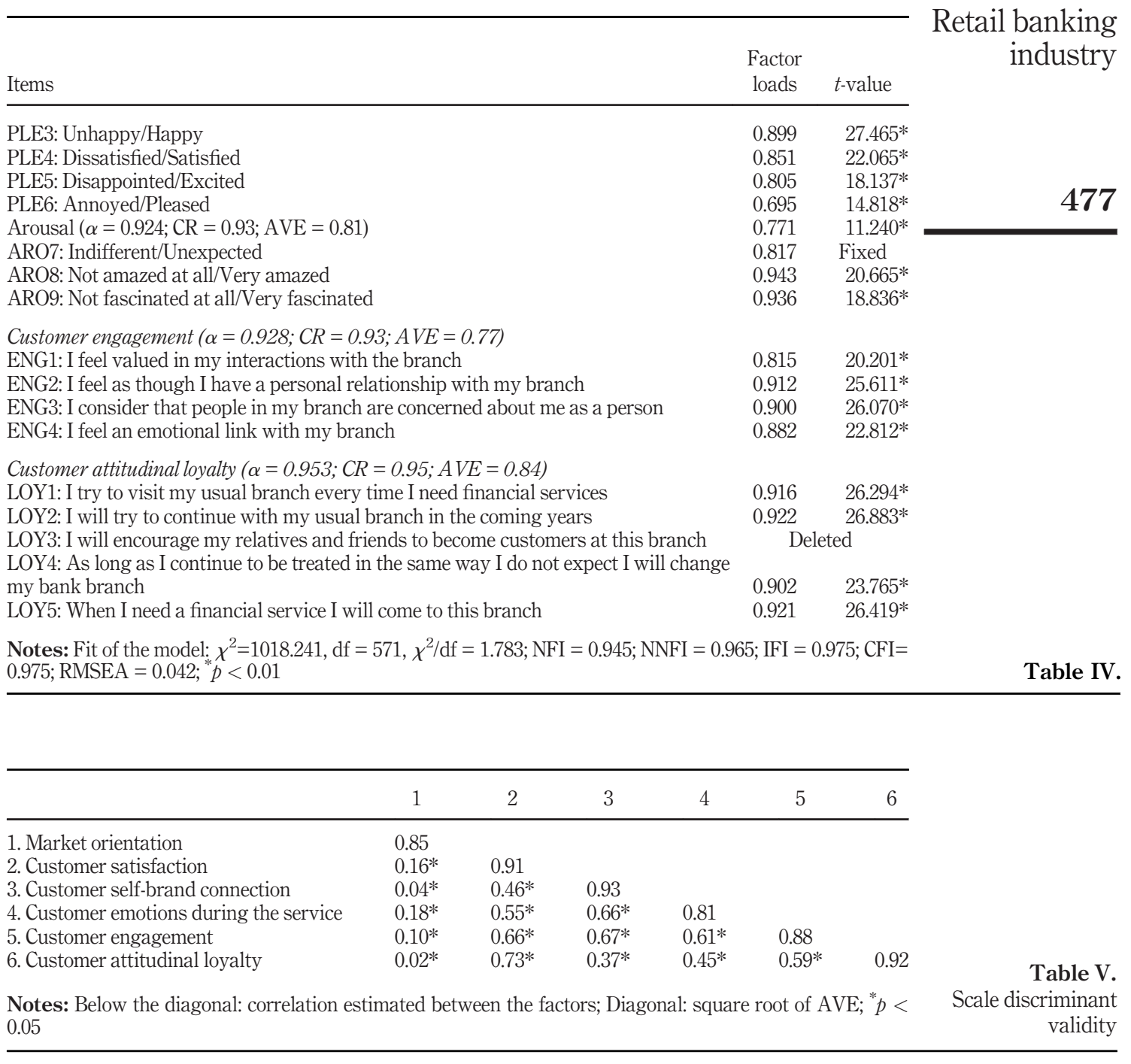

\section{Discussion and conclusions}

\subsection{Theoretical contributions}

This study aimed to explore the main antecedents of customer engagement (market orientation, satisfaction, emotions and self-brand connection) and the relationship between customer engagement and customer loyalty in the retail-banking context. The results reveal a strong association between customer engagement and customer loyalty (0.615). This finding attests to the relevance of customer engagement in generating customer loyalty, lending support to recent growing interest in the literature on this association (Kumar et al., 2013; Thakur, 2016; Kosiba et al., 2018; Moliner et al., 2018; Parihar et al., 2019). 
SJME

23,3

478

In this context, to explain how customer loyalty is generated, the antecedents of customer engagement must be analysed. This study drew on the framework of customer engagement put forward by Pansari and Kumar (2017), according to which customer engagement has two main antecedents (satisfaction and emotions). The main antecedent of customer engagement is customer satisfaction (0.552), followed by self-brand connection (0.372) and emotions during the service (0.218). Satisfaction is therefore the most important variable in generating engagement and loyalty. We can therefore conclude that customer satisfaction is a necessary condition to ensure customer engagement and customer loyalty. Firms in the retail-banking context must meet expectations in their service provision and information management.

Emotions also have an essential role to play in fostering engagement and loyalty; this is true for both emotions generated at the corporate level (self-brand connection) and those arising at the branch office level (emotions during the service). This result confirms the typology of emotions proposed by Ou et al. (2017) as both integral emotions (self-brand connection) and incidental emotions (emotions during the service) have a significant influence. In branding, self-congruency theory helps to explain customer loyalty through customer engagement. Customers' identification with the brand by matching their personality with the brand's values is a customer management strategy that firms should encourage. In turn, moments of truth that occur in the branch office are important in generating customer loyalty.

Moreover, our study demonstrates that adopting an intensive marketing strategy at the internal branch level, conceptualised through the construct of market orientation, favours a higher level of customer satisfaction (0.163) and more positive emotions in the provision of the service (0.203). A market orientation allows bank branches to understand their specific market needs, thus enhancing their understanding of the specific products/services that can best match the individual needs of each customer and implementing the available marketing activities and strategies that provide unique value to their customers (Fang et al., 2014; Kamboj and Rahman, 2015).

This study makes five relevant contributions. First, in response to recent calls in the literature for more in-depth analysis of this relationship (Kumar et al., 2013; Thakur, 2016; Kosiba et al., 2018; Moliner et al., 2018; Parihar et al., 2019), from the conceptual perspective it establishes a direct relationship between customer engagement and customer loyalty. Second, it empirically tested Pansari and Kumar's (2017) customer engagement framework, which establishes customer satisfaction and customer emotions as the antecedents of customer engagement. Third, the study took an innovative step in establishing two levels of customer emotions in the retail bank context: emotions generated by corporate branding and emotions that arise during the experience of purchase and consuming.

Fourth, our study shows that the market orientation adopted at the individual branch level is crucial to the generation of positive relational outcomes in the service the customer receives. Our

\begin{tabular}{|c|c|c|c|c|}
\hline Hyp. & Path & Parameter & $t$-value & Result \\
\hline$H 1$ & Self-brand connection $\rightarrow$ Engagement & 0.372 & $9.603^{*}$ & Supported \\
\hline H2 & Satisfaction $\rightarrow$ Engagement & 0.552 & $13.643^{*}$ & Supported \\
\hline$H 3$ & Emotions during the service $\rightarrow$ Engagement & 0.218 & $5.321^{*}$ & Supported \\
\hline H4 & Market orientation $\rightarrow$ Satisfaction & 0.163 & $3.220^{*}$ & Supported \\
\hline H5 & Market orientation $\rightarrow$ Emotions during the service & 0.203 & $3.328^{*}$ & Supported \\
\hline H6 & Engagement $\rightarrow$ Attitudinal loyalty & 0.615 & $12.893 *$ & Supported \\
\hline
\end{tabular}

Table VI.

Summary results of the structural model
Notes: Fit of the model: $\chi^{2}=1437.770, \mathrm{df}=579, \chi^{2} / \mathrm{df}=2.483 ; \mathrm{NFI}=0.922 ; \mathrm{NNFI}=0.934 ; \mathrm{IFI}=0.952 ; \mathrm{CFI}$ $=0.951 ;$ RMSEA $=0.057 ; p<0.01$ 
findings therefore provide empirical evidence of the gap in the literature analysing the view of lower-level managers in the pursuit of enhanced relationship quality with customers (Lam et al., 2010; Theodosiou et al., 2012). However, lower-level managers should be consulted if relational performance is to improve, particularly in service organisations. Lower-level managers are in direct contact with customers and must also nurture an effective culture of market orientation so customer contact employees will implement a market-oriented strategy that will favour customer satisfaction (Cadwallader et al., 2010; Lam et al., 2010).

Our fifth contribution is related to the fact that the research streams associated with market industry orientation and relationship quality have traditionally been studied in isolation. This is largely because of the different publics on which each of these streams focuses its analysis. Thus, on the one hand, organisational approaches on the strategic orientations firms adopt in their conceptions of their customer services (principally the market orientation from the marketing discipline) have tended to be integrated in models of effects on organisational variables (Zhang and Duan, 2010; Al Mamun et al., 2018; Monferrer et al., 2019). In turn, research on the variables that contribute to the quality of the relationship has chiefly focused on the customer (Moliner et al., 2018). The methodological approach using the branch-customer dyads adopted in this study has enabled us to integrate the two streams in the same causal model. Therefore, although earlier studies have demonstrated the positive effects on the commercial and relational activity of constructs linked to these theoretical perspectives, we are unaware of any previous research that develops a reasoned theoretical framework to jointly consider these perspectives in the same model, and by extension, how these variables might interrelate, to improve relationships with customers, either directly or indirectly.

\subsection{Managerial implications}

Bank managers must bear in mind that customer satisfaction is the main antecedent of customer engagement and customer loyalty, and both aspects should therefore be carefully considered when designing value propositions for retail bank products and services. Similarly, the retail bank sector should manage expectations in such a way that they are realistic and attractive.

The moments of truth in branch offices are crucial aspects in the retail bank strategy. Not only do they play a determining role in generating customer satisfaction but the purchase experience also arouses emotions that influence customer engagement and customer loyalty.

To achieve these factors, a high degree of market orientation must be developed internally in the branch, which ensures an understanding of its customers' needs, the specific context in which it develops its own activity, and the optimal use of the marketing resources the company provides at a corporate level. As one of the senior marketing managers we interviewed said:

Banks have had to break out of the straitjacket that completely restricted the branches' movements, since the reality is that each branch is an individual entity with very different characteristics.

Each branch operates in a specific context, and each context may differ considerably from that of other branches in terms of customer type, business turnover, environmental conditions, needs for specific products and services and so on. Branch managers must therefore be given the flexibility to apply general directives according to local criteria so as to meet their own particular targets. As we have shown in this study, there is a need for an ongoing commitment at the branch level to developing a market orientation that, through the efficient management of specific market knowledge, helps to construct a unit that carries out its own particular activity according to its context. Selecting and training staff who deal 
SJME

23,3

directly with the public is therefore a vital aspect of strategy. The design of the branch office, with careful attention to merchandising, interactions among customers and the area where the public are attended, are all critical aspects in successful relationship marketing.

However, the current reality is one of a growing tendency in the retail bank sector to cut back the number of branches in a drive to become more productive and profitable, a consequence of the low operating margins in recent years. This strategy may appear to be inconsistent with the model tested in this study in that our results seem to advocate strengthening relationship marketing at the branch office level. On a related note, emotional links (based on relationships established with customers) tend to arise from personal interaction between contact personnel and customers. If these interactions are reduced to a minimum, the firm-customer connection will essentially be of a rational nature, and therefore not as sustainable.

It must be said, however, that this interpretation does not align well with the real situation. In this new landscape in which online banking is gaining ground on branch offices, the model shows that customer satisfaction must be analysed in the context of internet banking and customer emotions during the online service. Clearly, the strategic parameters of the online environment do not coincide with those of the branch office, but the essence of customer engagement (customer satisfaction and customer emotions) remains the same.

\subsection{Limitations and future research}

The study has several limitations. The first concerns the transversal data used. Studying how the variables evolve over time would obviously be extremely enlightening. Geographical context is the second limitation. Although the bank studied is large enough to be included in the list of Spain's top ten banks, we analysed a specific geographical area that did not cover all its markets. Third, the study sample only included customers with experience of the financial services of a specific bank (online customers were not included). Caution should therefore be taken when generalising the results to potential customers with no experience of this financial brand. Finally, the dyads are based on the opinion of the branch manager, on one hand, and an average of five customers per branch on the other. Although this number falls in line with recommendations in the literature (Yoon and Suh, 2003), it would be useful to increase the average number of customers interviewed in each branch to improve the accuracy of the results.

Various lines of future research emerge from this study. First, it would be useful to analyse the causal model according to customer age. We assume that behaviour will not be the same among millennials as seniors, which could have a considerable impact on marketing strategies. In light of the relentless technological revolution and ensuing lower staff levels, a second area for future study is to examine customer engagement in the online context. The percentage of bank customers that carry out all their transactions on line and use few face-to-face banking services is rising. Although this provides a fascinating field of study from the co-creation perspective, it poses new challenges in the engagement era. Finally, future research might also be tested in other countries and international settings to verify whether the results can be generalised.

\section{References}

Aguirre, A., Bosnjak, M. and Sirgy, M.J. (2012), "Moderators of the self-congruity effect on consumer decision-making: a meta-analysis", Journal of Business Research, Vol. 65 No. 8, pp. 1179-1188.

Al Mamun, A., Mohiuddin, M., Fazal, S.A. and Ahmad, G.B. (2018), "Effect of entrepreneurial and market orientation on consumer engagement and performance of manufacturing SMEs", Management Research Review, Vol. 41 No. 1, pp. 133-147. 
Anderson, E.W. and Mittal, V. (2000), "Strengthening the satisfaction-profit chain", Journal of Service Research, Vol. 3 No. 2, pp. 107-120.

Bagozzi, R.P., Gopinath, M. and Nyer, P. (1999), "The role of emotions in marketing”, Journal of the industry Academy of Marketing Science, Vol. 27 No. 2, pp. 184-206.

Batko, J.J. (1976), "On various intraclass correlation reliability coefficients", Psychological Bulletin, Vol. 83 No. 5 , pp. $762-765$.

Blasco, L. (2014), "Los procesos de co-creación y el engagement del cliente: un análisis empírico en medios interactivos", Doctoral dissertation. Universidad de Zaragoza, Zaragoza.

Bloemer, J.M.M. and Odekerken, G. (2002), "Store satisfaction and store loyalty explained by customerand store related factors", Journal of Consumer Satisfaction, Dissatisfaction and Complaining Behaviour, Vol. 15 No. 2, pp. $68-80$.

Bowden, J.L.H. (2009), "The process of customer engagement: a conceptual framework", Journal of Marketing Theory and Practice, Vol. 17 No. 1, pp. 63-74.

Brodie, R.J., Hollebeek, L.D., Juric, B. and Ilic, A. (2011), "Customer engagement: conceptual domain, fundamental propositions, and implications for research", Journal of Service Research, Vol. 4 No. 3, pp. 252-271.

Cadwallader, S., Jarvis, C.B., Bitner, M.J. and Ostrom, A.L. (2010), "Frontline employee motivation to participate in service innovation implementation", Journal of the Academy of Marketing Science, Vol. 38 No. 2, pp. 219-239.

Camarero, M.C., Gutiérrez, J. and San Martín, S. (2005), "The impact of customer relationship marketing on the firm performance: a Spanish case", Journal of Services Marketing, Vol. 19 No. 4, pp. 234-244.

Cambra, J., Melero, I. and Sesé, F.J. (2016), "Can complaint-handling efforts promote customer engagement?", Service Business, Vol. 10 No. 4, pp. 847-866.

Chahal, H. and Dutta, K. (2015), "Measurement and impact of customer experience in banking sector", DECISION, Vol. 4 No. 21, pp. 57-70.

Chaplin, L.N. and John, D.R. (2005), "The development of self-brand connections in children and adolescents", Journal of Consumer Research, Vol. 32 No. 1, pp. 119-129.

Churchill, G.A. Jr (1979), "A paradigm for developing better measures in marketing”, Journal of Marketing Research, Vol. 16 No. 1, pp. 64-73.

Csikósová, A., Čulková, K. and Janošková, M. (2016), "Evaluation of quantitative indicators of marketing activities in the banking sector", Journal of Business Research, Vol. 69 No. 11, pp. 5028-5033.

Davis, R.E., Couper, M.P., Janz, N.K., Caldwell, C.H. and Resnicow, K. (2010), "Interviewer effects in public health surveys", Health Education Research, Vol. 25 No. 1, pp. 14-26.

De Matos, C.A., Henrique, J.L. and De Rosa, F. (2009), "The different roles of switching costs on the satisfaction-loyalty relationship", International Journal of Bank Marketing, Vol. 27 No. 7, pp. 506-523.

Dick, A.S. and Basu, K. (1994), “Customer loyalty: toward an integrated conceptual framework”, Journal of the Academy of Marketing Science, Vol. 22 No. 2, pp. 99-113.

El-Manstrly, D., Paton, T., Veloutsou, C. and Moutinho, L. (2011), "An empirical investigation of the relative effect of trust and switching costs on service loyalty in the UK retail banking industry", Journal of Financial Services Marketing, Vol. 16 No. 2, pp. 101-110.

Escalas, J.E. (2004), "Narrative processing: building consumer connections to brands", Journal of Consumer Psychology, Vol. 14 Nos 1/2, pp. 168-180.

Escalas, J.E. and Bettman, J.R. (2005), “Self-construal, reference groups, and brand meaning”, Journal of Consumer Research, Vol. 32 No. 3, pp. 378-389.

Fang, S.R., Chang, E., Ou, C.C. and Chou, C.H. (2014), "Internal market orientation, market capabilities and learning orientation", European Journal of Marketing, Vol. 48 Nos 1/2, pp. 170-192. 
Farrell, M.A. and Oczkowski, E. (2009), "Service worker customer orientation, organisation/job fit and perceived organisational support", Journal of Strategic Marketing, Vol. 17 No. 2, pp. 149-167.

Ferreira, F.A.F., Jalali, M.S., Ferreira, J.J.M., Stankeviciene, J. and Marques, C. (2016), “Understanding the dynamics behind bank branch service quality in Portugal: pursuing a holistic view using fuzzy cognitive mapping", Service Business, Vol. 10 No. 3, pp. 469-487.

Flavián, C. and Lozano, J. (2006), "Organisational antecedents of market orientation in the public university system”, International Journal of Public Sector Management, Vol. 19 No. 5, pp. 447-467.

Fornell, C. and Larcker, D.F. (1981), "Evaluating structural equation models with unobservable variables and measurement error", Journal of Marketing Research, Vol. 18 No. 1, pp. 39-50.

Frijda, N.H., Kuipers, P. and Schure, T.E. (1989), "Relations among emotion, appraisal and emotional action readiness", Journal of Personality and Social Psychology, Vol. 57 No. 2, pp. 212-228.

Füller, H. (2010), "Refining virtual co-creation from a consumer perspective", California Management Review, Vol. 52 No. 2, pp. 98-122.

Garg, N., Inman, J.J. and Mittal, V. (2005), "Incidental and task-related affect are-inquiry and extension of the influence of affect on choice", Journal of Consumer Research, Vol. 2 No. June, pp. 154-159.

Gensler, S., Leeflang, P. and Skiera, B. (2013), "Comparing methods to separe treatment from selfselection effects in an online banking setting", Journal of Business Research, Vol. 66 No. 9, pp. 1271-1278.

Glick, W.H. (1985), "Conceptualizing and measuring organizational and psychological climate: pitfalls in multilevel research", Academy of Management Review, Vol. 10 No. 3, pp. 601-616.

Hair, J.F., Black, W.C., Babin, B.J. and Anderson, R.E. (2010), Multivariate Data Analysis, Prentice Hall, Upper Saddle River, NJ.

Han, J.K., Kim, N. and Srivastava, R.K. (1998), "Market orientation and organizational performance: is innovation a missing link?”, Journal of Marketing, Vol. 62 No. 4, pp. 30-45.

Harrigan, P., Evers, U., Miles, M.P. and Daly, T. (2018), "Customer engagement and the relationship between involvement, engagement, self-brand connection and brand usage intent", Journal of Business Research, Vol. 88, available at: https://doi.org/10.1016/j.jbusres.2017.11.046

Hollebeek, L.D. (2011), "Demystifying customer brand engagement: exploring the loyalty nexus", Journal of Marketing Management, Vol. 27 Nos 7/8, pp. 785-807.

Hollebeek, L.D. and Chen, T. (2014), "Exploring positively-versus negatively-valenced brand engagement: a conceptual model", Journal of Product and Brand Management, Vol. 23 No. 1, pp. 62-74.

Hox, J.J. (1994), "Hierarchical regression models for interviewer and respondent effects", Sociological Methods and Research, Vol. 22 No. 3, pp. 300-318.

Jaakkola, E. and Alexander, M. (2014), "The role of customer engagement behavior in value co-creation: a service system perspective”, Journal of Service Research, Vol. 17 No. 3, pp. 247-261.

James, L.R. (1982), "Aggregation bias in estimates of perceptual agreement”, Journal of Applied Psychology, Vol. 67 No. 2, pp. 219-229.

Jöreskog, K. and Söbom, D. (1993), LISREL 8: Structural Equation Modeling with the SIMPLIS Command Language, Scientific Software International, Chicago, IL.

Kamboj, S. and Rahman, Z. (2015), "Marketing capabilities and firm performance: literature review and future research agenda", International Journal of Productivity and Performance Management, Vol. 64 No. 8, pp. 1041-1067.

Kamran, O., Mantrala, M.K., Izquierdo, A. and Martínez, M.P. (2017), "The impact of retail store format on satisfaction-loyalty link: an empirical investigation", Journal of Business Research, Vol. 77 No. 1, pp. 14-22. 
Kemp, E., Jillapalli, R. and Becerra, E. (2014), "Healthcare branding: developing emotionally based consumer brand relationships", Journal of Services Marketing, Vol. 28 No. 2, pp. 126-137.

Kitayama, S., Markus, H.R. and Kurokawa, M. (2000), "Culture, emotion, and well-being: good feelings industry in Japan and the United States", Cognition and Emotion, Vol. 14 No. 1, pp. 93-124.

Klaus, P., Gorgoglione, M., Buonamassa, D., Panniello, U. and Nguyen, B. (2013), “Are you providing the 'right' customer experience? The case of Banca popolare di Bari”, International Journal of Bank Marketing, Vol. 31 No. 7, pp. 506-528.

Kohli, A.K. and Jaworski, B.J. (1990), "Market orientation: the construct, research propositions and managerial implications", Journal of Marketing, Vol. 54 No. 2, pp. 1-18.

Kolar, T. (2006), "Benchmarking market orientation of banks in transitional markets: exploring a modified approach", International Journal of Bank Marketing, Vol. 24 No. 2, pp. 76-97.

Kosiba, J.P.B., Boateng, H., Okoe Amartey, A.F., Boakye, R.O. and Hinson, R. (2018), "Examining customer engagement and brand loyalty in retail banking: the trustworthiness influence", International Journal of Retail and Distribution Management, Vol. 46 No. 8, pp. 764-779.

Kumar, V., Pozza, I.D. and Ganesh, J. (2013), "Revisiting the satisfaction-loyalty relationship: empirical generalizations and directions for future research", Journal of Retailing, Vol. 89 No. 3, pp. 246-262.

Lam, S.K., Kraus, F. and Ahearne, M. (2010), "The diffusion of market orientation throughout the organization: a social learning theory perspective”, Journal of Marketing, Vol. 74 No. 5, pp. 61-79.

Lings, I. and Greenley, G. (2009), "The impact of internal and external market orientations on firm performance", Journal of Strategic Marketing, Vol. 17 No. 1, pp. 41-53.

Martin, D., O'Neill, M., Hubbard, S. and Palmer, A. (2008), “The role of emotion in explaining consumer satisfaction and future behavioral intention”, Journal of Services Marketing, Vol. 22 No. 3, pp. 224-236.

Mazaheri, E., Richard, M. and Laroche, M. (2011), “Online consumer behavior: comparing Canadian and Chinese website visitors”, Journal of Business Research, Vol. 64 No. 9, pp. 958-965.

Medlin, B. and Green, K.W. (2009), "Enhancing performance through goal setting, engagement and optimism”, Industrial Management and Data Systems, Vol. 109 No. 7, pp. 943-956.

Moliner, M.A., Monferrer, D. and Estrada, M. (2018), "Consequences of customer engagement and customer self-brand connection”, Journal of Services Marketing, Vol. 32 No. 4, pp. 387-399.

Monferrer, D., Moliner, M.A. and Estrada, M. (2019), “Ambidexterity as a key factor in banks' performance: a marketing approach”, Journal of Marketing Theory and Practice, Vol. 27 No. 2, pp. 227-250.

Narver, J.C. and Slater, S.F. (1990), “The effect of a market orientation on business profitability”, Journal of Marketing, Vol. 54 No. 4, pp. 20-35.

Oliver, R.L. (1999), “Whence consumer loyalty?”, Journal of Marketing, Vol. 63 No. 4_suppl1, pp. 33-44.

Ou, Y.C., Verhoef, P.C. and Wiesel, T. (2017), "The effects of customer equity drivers on loyalty across services industries and firms", Journal of the Academy of Marketing Science, Vol. 45 No. 3, pp. 336-356.

Palmatier, T.W., Dant, R.P., Grewal, D. and Evans, K.R. (2006), "Factors influencing the effectiveness of relationship marketing: a meta-analysis", Journal of Marketing, Vol. 70 No. 4, pp. 136-153.

Pansari, A. and Kumar, V. (2017), "Customer engagement: the construct, antecedents, and consequences”, Journal of the Academy of Marketing Science, Vol. 45 No. 3, pp. 294-311.

Parihar, P., Dawra, J. and Sahay, V. (2019), "The role of customer engagement in the involvementloyalty link", Marketing Intelligence and Planning, Vol. 37 No. 1, pp. 66-79.

Podsakoff, P.M., Mackenzie, S.B., Lee, J.Y. and Podsakoff, N.P. (2003), "Common method biases in behavioral research: a critical review of the literature and recommended remedies", Journal of Applied Psychology, Vol. 88 No. 5, pp. 879-903. 
Roy, S.K., Balaji, M.S., Soutar, G., Lassar, W.M. and Roy, R. (2018), “Customer engagement behavior in individualistic and collectivistic markets", Journal of Business Research, Vol. 86, available at: http://dx.doi.org/10.1016/j.jbusres.2017.06.001

Schneider, B. and Bowen, D.E. (1985), "Employee and customer perceptions of services in banks: replication and extension", Journal of Applied Psychology, Vol. 70 No. 3, pp. 423-433.

Serna, R. (2005), "Where are the bank branches in my community? An analysis of branch distribution in low-income neighborhoods", California Reinvestment Coalition Report, available at: www.calreinvest.org

Sirgy, M.J. (1985), "Using self-congruity and ideal congruity to predict purchase motivation”, Journal of Business Research, Vol. 13 No. 3, pp. 195-206.

Sirgy, M.J., Lee, D.J., Johar, J.S. and Tidwell, J. (2008), "Effect of self-congruity with sponsorship on brand loyalty", Journal of Business Research, Vol. 61 No. 10, pp. 1091-1097.

Sprott, D., Czellar, S. and Spangenberg, E. (2009), "The importance of general measure of brand engagement on market behavior: development and validation of a scales", Journal of Marketing Research, Vol. 46 No. 1, pp. 92-104.

Steenkamp, J.E.M. and Van Trijp, H.C.M. (1991), "The use of LISREL in validating marketing constructs", International Journal of Research in Marketing, Vol. 8 No. 4, pp. 283-299.

Thakur, R. (2016), "Understanding customer engagement and loyalty: a case of mobile devices for shopping", Journal of Retailing and Consumer Services, Vol. 32, pp. 151-163.

Theodosiou, M., Kehagias, J. and Katsikea, E. (2012), "Strategic orientations, marketing capabilities and firm performance: an empirical investigation in the context of frontline managers in service organizations", Industrial Marketing Management, Vol. 41 No. 7, pp. 1058-1070.

Van Doorn, J., Lemon, K.N., Mittal, V., Nass, S., Pick, D., Pirner, P. and Verhoef, P.C. (2010), "Customer engagement behavior: theoretical foundations and research directions", Journal of Service Research, Vol. 13 No. 3, pp. 253-266.

Verhoef, P.C., Reinartz, W.J. and Krafft, M. (2010), "Customer engagement as a new perspective in customer management”, Journal of Service Research, Vol. 13 No. 3, pp. 247-252.

Verleye, K. (2015), "The co-creation experience from the customer perspective: its measurement and determinants", Journal of Service Management, Vol. 26 No. 2, pp. 321-342.

Ye, J., Marinova, D. and Singh, J. (2007), "Strategic change implementation and performance loss in the front lines", Journal of Marketing, Vol. 71 No. 4, pp. 156-171.

Yoon, M.H. and Suh, J. (2003), "Organizational citizenship behaviors and service quality as external effectiveness of contact employees”, Journal of Business Research, Vol. 56 No. 8, pp. 597-611.

Zhang, J. and Duan, Y. (2010), "The impact of different types of market orientation on product innovation performance", Management Decision, Vol. 48 No. 6, pp. 849-867.

Zhou, K.Z., Li, J.J., Zhou, N. and Su, C. (2008), "Market orientation, job satisfaction, product quality and firm performance: evidence from China", Strategic Management Journal, Vol. 29 No. 9, pp. $985-1000$.

\section{Corresponding author}

Miguel Angel Moliner can be contacted at: amoliner@uji.es

For instructions on how to order reprints of this article, please visit our website:

www.emeraldgrouppublishing.com/licensing/reprints.htm

Or contact us for further details: permissions@emeraldinsight.com 